\title{
JAVNA RIJEČ U MEĐURATNOM SPLITU
}

\section{Inoslav Bešker}

\author{
UDK: 316.774(497.5 Split)“1918/1941“ \\ Pregledni rad
}

Sažetak: Javna riječ u Splitu između dvaju svjetskih ratova odzvanjala je i u fizičkom i u medijskom prostoru kroz dva diskursa: usmeni (govorni) i pismeni. Realni prostor čine Općinsko vijeće, kavana ustrojena kao antički kor (s kriptoinstitucijom „stola mudraca“), tržnica i ribarnica kao mjesta razmjene i ideja, a ne samo roba. U realni prostor ubraja se i teatar, i kazališni i ulični (ne samo za karnevala). Od medija je prvotno dostupan praktički samo tisak (radio tek potkraj). U tisku dominiraju novine, kao poprište javne riječi namijenjene glasilima, ali podjednako i kao zrcalo javne riječi izrečene u drugim ambijentima, pa zabilježene parcijalno. S te strane nam tadašnje splitske novine služe ne samo kao sekundaran, nego počesto i kao primaran povijesni izvor i značajan dokument javne riječi u međuratnom Splitu. Standardi novinskog diskursa i žurnalističke kulture, razvijeni u međuratnom Splitu, utjecali su preko svojih izravnih aktera (Ive Baljkasa, Jerolima Cogelje itd.) na razinu novinskog diskursa i žurnalističku kulturu u Hrvatskoj nakon Drugoga svjetskog rata.

Ključne riječi: Split, međuratno razdoblje, javna riječ, medij, diskurs, novine, Ivo Baljkas, Jerolim Čogelja, Josip Kortšek

rađansko društvo međuratnog Splita koji se, gubitkom Zadra, neočekivano našao u političkom središtu Dalmacije, iskazuje ako ne sebe, a ono sliku o sebi baš kroz javnu riječ, političku i kriptopolitičku, kulturalnu koja je i antropološka, katkada i nehoteć. Protagonisti javne scene katkad postupaju iza kulisa, ali istupaju pod reflektorima.

Nema doba u pisanim kronikama Splita, od Tome Arhiđakona do Ante Tomića, da se taj grad nije polarizirao i antagonizirao, bez obzira na to što je i tko posrijedi, no svakako utoliko žešće ukoliko su pojedinac ili pojava izvan uštogljenih gabarita. Ti antagonizmi su vjekovni dvotaktni motor koji štekće i javnim prostorom i javnom riječju, između državotvoraca i anarhoida, između talijanaša i narodnjaka, austrofila i jugofila, pa između unitarista i separatista, crvenih i crnih, tušičara i vršičara ${ }^{1}$ i tako dalje. Nema pobjede dovoljno velike da to prevlada. Kad su pobijedili gibeline, guelfi su se u Firenci jednako zakrvljeno podijelili na bijele i crne - a Split pripada istoj kulturalnoj ekumeni.

1 Tako su, u Velikanovićevu prijevodu Gulliverovih putovanja, definirane stranke u Liliputu. Usp. Jonathan SwIFT, Gulliverova putovanja, Zagreb 1955. 
Težnje i frustracije, smjelost i autocenzura, čine sastavni dio javnog i generalnog diskursa u tim gotovo trima desetljećima dvaju svjetskih ratova odnosno - po ne posve neutemeljenoj sintezi - dvaju činova istoga svjetskog rata, koji, po nekim naznakama, u našoj javnoj riječi još nije dovršen.

\section{NOVINE KAO PRIMARNI IZVOR}

Ni učenjaci izvan povjesničarske struke ne mogu uteći od nekih povjesničarskih metoda, ne samo u povijesti književnosti, umjetnosti, znanosti itd., nego i u svakoj disciplini koja se ovako ili onako bavi čovječanstvom, poglavito njegovim živčevljem, dakle komunikacijama, dakako i novinskima. Efemernost je karakteristika novina - nisu li se, napokon, prve novine izdavane na teritoriju današnje Hrvatske zvale Ephemeridae Zagrabiensis? A ipak korištenje novinskoga bibliotečnog fonda, naših hemeroteka, ne mora biti samo razbibriga dokonih ili duševna hrana čudaka koji ištu reportaže i reklame iz davnih desetljeća, nego i onih koji u njima traže odraz njihova doba, kao u „zrcalu svog vremena“ - kako je to sročio Josip Horvat ${ }^{3}$ (nipošto jedini autor koji je pisao i kroniku i povjesnicu) - ili vjeruju da je novinarstvo „povjesnica trenutka“, kako se dosjetio Umberto Eco. ${ }^{4}$

Takve teze o povjesničarskim valerima novinstva ne datiraju ni iz ovoga ni iz prošlog stoljeća. One i same pripadaju u povijest: Théophraste Renaudot još je 1631. pokrenuo tjednik Gazette 5 kako bi pripovijedao „dnevnu povijest“, ", „tjednu povijest“, ", povijest svog vremena“ te je u istu svrhu rečeni tjednik komplementirao 1633. mjesečnikom Relations, ${ }^{8} \mathrm{u}$ kojemu bi,

$2 \quad$ Držimo li se zanemarene, ali korisne distinkcije između znanosti (sciencia, Wissenschaft, science...) i nauka (studium, bez pretenzije da bude doctrina, dakle Lehre, enseignement, teaching), moramo se kloniti ambicije da svako kopanje po listinama uzdižemo na pijedestal znanosti, kao da iznosimo dotad nedosegnuto znanje, izvornu teoriju. Učenjak je prikladna inačica pojma studiosus, Gelehrter, lettré, scholar, studioso - a i dovoljno dostojna.

3 Josip Horvat, Povijest novinstva Hrvatske 1771-1939., Zagreb 1962., 18. Usp. i: Josip Horvat, „Društveni spektar stoljeća novinstva Hrvatske 1835.-1935.“, Jugoslovenski istorijski časopis, 7/1968., br. 3-4, 39-56.

4 Izvorno: „storiografia dell'istante“. Usp. Umberto Eco, „Obiettività dell'informazione: il dibattito teorico e le trasformazioni della società italiana“, u: Umberto Eco - Marino Livolsi - Giovanni Panozzo, Informazione, consenso e dissenso, Milano 1979., 34. Na tom mjestu Eco poziva novinare da budu „povjesničari sadašnjosti i trenutka“ („storici del presente o dell'istante“). Drugdje kaže npr.: „Il giornalista è uno storico del presente, ma non sempre i buoni libri di storia si scrivono in un giorno, spesse volte in un'ora, spesse volte in un minuto." Navedeno prema: http:// aforismi.meglio.it/aforisma.htm?id=4cb0. Neki novinari pak kažu da je „povjesničar sadašnjosti“" oksimoron jer da nema povjesničara bez distance. Usp. npr. Gian Guido Vecchi u: Comunicazione e giornalismo: nuove vie e vecchie questioni, Milano 2012., 15 (http://www.ceur.it/System/13353/Quaderno\%20Ceur_1_per\%20web.pdf).

5 Jean Lacouture, Les impatients de l'histoire, Paris 2009., 5.

6 Navedeno prema: Eugène Hatin, Histoire politique et littéraire de la presse en France, sv. 1, Paris 1859., 143 (https:// fr.wikisource.org/wiki/Histoire_politique_et_litt\%C3\%A9raire_de_la_presse_en_France/Partie_1).

7 „Préface du Recueil des gazettes de l'année 1631“, nav. prema: Gilles FeyeL, „Aux origines de l'éthique des journalistes: Théophraste Renaudot et ses premiers discours éditoriaux (1631-1633)“, Le Temps des médias, 1/2003., br. 1, 175-189 (http://www.histoiredesmedias.com/Aux-origines-de-l-ethique-des.html\#2). Naime, na kraju svake godine svi listovi Gazette bi se uvezivali u jedan svezak, za koji je Renaudot pisao predgovor (Préface). Na taj je način tjednik postajao izvor i za povjesničare, ali i za književnike-feljtoniste. Tim se izvorom obilato služio Alexandre Dumas pišući trilogiju o mušketirima. Usp. Christian Jounaud, Les pouvoirs de la littérature. Histoire d'un paradoxe, Paris 2000., poglavlje III, „Historiens du temps présent et pouvoir politique“, 151-250.

8 E. Hatin, Histoire politique et littéraire de la presse en France, 85. Punim nazivom: Relations des nouvelles du monde reçues dans tout le mois. Za njih Renaudot na istom mjestu kaže: „Ces miennes relations de chaque mois, dit-il, servent de lumière et d'abrégé à celles des semaines; car il est des nouvelles comme des métaux: ceux-ci, au sortir de la mine, 
s odmakom od striktne aktualnosti, stavljajući vijesti u kontekst, mogao iznositi „dnevnu povijest... godine“.? Upravo je taj kroničarski novinski trud Renaudotu, po zagovoru „Sive Eminencije“, tj. o. Josepha, priskrbio naslov „povjesničara Njegova Veličanstva“.10

O odnosu novinara spram povjesnice i povjesničara ima više poučnih i mahom metodoloških rezimea, koje ovdje nema ni prostora ni svrhe citirati. Valja ipak reći da se o novinama sve češće govori i kao o primarnome, a ne samo sekundarnom izvoru. ${ }^{11}$

I tu je dobro prisjetiti se izreke Qui bene distinguit, bene docet. ${ }^{12}$ Niti je sve u novinama povjesničarski izvor, niti je svaki izvor u njima primaran. Izvještavanje je jamačno sekundaran izvor. Primaran izvor može biti intervju, može biti i reportaža. Može to biti i izvorni članak iz pera javne osobe, protagonista javne riječi. Ako, primjerice, istražujemo djelovanje Vladana Desnice u Splitu, nema dvojbe da će u primarne izvore biti uvršteni i tekst objavljen u Novom dobu. Primarni izvori mogu biti i ankete među građanima o raznim pitanjima. I tako dalje.

Kao i bilo koji primarni izvor, tako i novinski (odnosno generalno medijski) valja pažljivo verificirati, s obzirom na autora i s obzirom na kontekst. Poznato je da ne postoji neutralan pisani dokument jer ne može ne reflektirati stavove i eventualna ograničenja onoga koji ga je pisao ili koji je, naprosto, prethodno odlučivao što je vrijedno, a što nužno zabilježiti (što znači: odabrati iz mogućeg poklada podataka, inače prepuštenih entropiji). Čak se i puka činjenica, objavljena u nekom glasilu, može dovesti u pitanje ${ }^{13}$ jer ne postoji informacija in abstracto, ${ }^{14}$ nego ovisi o subjektivnom gledištu novinara autora, odnosno urednika. ${ }^{15}$

U novinama i općenito u medijskom bilježenju entropiji mogu, neovisno o nakani onoga tko bilježi, pridonijeti faktori brzine i neposrednosti. Te je faktore nemoguće izbjeći: i brzina i neposrednost pripadaju u kriterije za odabir medijskih sadržaja. ${ }^{16}$ Nadalje, novin-

sont volontiers mêlés de quelque terre; celles-là d'abord sont ordinairement accompagnées de quelques circonstances mal entendues, dont elles s'épurent avec un peu de temps, comme font les autres étant jetés dans leurs lingotières. Alors vous les avez en leur naïveté..."

9 „...l'histoire journalière de cette année“, „Relation de décembre 1633“, nav. prema G. Feyel, „Aux origines de l'éthique des journalistes“.

$10 \mathrm{Tj}$. „historiographe de Sa Majesté“. E. Hatin, Histoire politique et littéraire de la presse en France, 143.

11 „A serial is a publication, such as a magazine, newspaper, or scholarly journal, that is published in ongoing installments. Like books, serials can function both as primary sources and secondary sources depending on how one approaches them." Usp. Primary Sources at Yale (http://www.yale.edu/collections_collaborative/primarysources/primarysources.html).

12 U prijevodu: „Dobro poučava tko pomno razlikuje.“ Pripisana je obično sv. Augustinu; donosi je Jan Amos Komenský (Comenius). Usp. Didactica magna, DK 15, 145.34 i dalje, što razrađuje i na inome mjestu: „Rerum nosse differentias est res nosse (...) ergo qui bene distinguit, bene docet“, Novissima linguarum methodus, DK $15^{\mathrm{II}}$, 190.45 i dalje.

$13 \ldots$ „...iza činjenice uvijek već stoji činitelj, pa i pojam činjenice dolazi od $u$-činjenice, tj. od nečega što je moralo biti tek učinjeno da bi uopće bilo. Stoga i pozivanje na činjenice promašuje u bitnome, ako se ujedno ne pita za koga ili po kome su to činjenice.“ Milan Kangrga, „Etika i novinarstvo“, Medijska istraživanja, 4/1988., br. 1, 18. Istaknuto u originalu (nap. I. B.).

14 „Iza nje svagda stoji netko tko je daje, u ovom slučaju novinar.“ Novinar je „sav prisutan u svakoj informaciji, pa se stoga i ne može skrivati tobože iza neke, u ovom slučaju apstraktne puke činjenice, jer je to njegova činjenica! Kako će je on iznijeti, upravo u tome leži čitava stvar.“ M. KANGRGA, „Etika i novinarstvo“, 19.

15 „...même si la nouvelle 'brute’ - c’est-à-dire l'actualité immédiate - est en principe précise, le point de vue subjectif du chroniqueur ou du rédacteur risque de colorer son interprétation de l'événement..." Usp. Les journaux et la recherche historique, Royal Alberta Museum (http://www.royalalbertamuseum.ca/exhibits/online/gwg/fr/enseignants/ lesjournaux.html).

16 Potanje o neposrednosti: Andrew Boyd, Broadcast Journalism. Techniques of Radio and TV News, Oxford 1994. 
ski sadržaj može, bez obzira na nakane i stavove autora, biti podvrgnut metodama kvantitativne, odnosno kvalitativne analize. Te metode omogućuju ekstrapoliranje podataka ili trendova i iz objavljenih novinskih sadržaja. ${ }^{17}$

Rezimirajući prosudbe od Renaudota, preko Enzensbergera i Naisbitta, do sada već nebrojenih pisaca sveučilišnih i časopisnih naputaka (poput citiranih s Yalea), pretpostavljam, dakle, da možemo reći da i novine mogu biti primarni izvor, vjerodostojan pod istim uvjetima kao i ini tradicionalno prihvaćeni primarni izvori. Među njima novine imaju i jednu poredbenu prednost: ako i jesu izložene subjektivnosti u odabiru i interpretaciji, katkad i više od inih izvora, pouzdanije od njih mogu prikazati percepciju i fenomena i osoba u doba kada su tiskane.

\section{OPSEg I PROSTOR JAVNE RIJEČI}

I opis i analiza javne riječi u međuratnom Splitu moraju se osloniti prvenstveno na novinski medij kao izvor. Izravna svjedočenja insajdera sada su već nemoguća. Njihovi zapisi su oskudni.

Novinski medij ipak nije u razdoblju 1918. - 1945. bio ni jedini, pa zapravo ni pretežan prostor javne riječi. Ona je u međuratnom Splitu odjekivala mnogo češće, a zapravo i prodornije, u fizičkom prostoru nego u medijskome. Naravno, onodobnome govornom diskursu kairós je odavna utekao, ostale su samo njegove zapisane sjene, ali i tragovi u kolektivnom imaginariju. Pismeni diskurs opstaje, ali se, razasut po glasilima, doima Kumovom slamom u kojoj tek valja tražiti poslovične igle.

Naime, Novo doba u široj lepezi te ostali listovi raznih užih usmjerenja - od Pobede do Hrvatskog glasnika - ili raznih interesa - poput Jadranskog Lloyda, uključujući i satiričke od obnovljenoga Duje Balavca do Štandarca - bili su i poprište javne riječi namijenjene glasilima, ali podjednako i zrcalo javne riječi izrečene u drugim ambijentima, pa zabilježene parcijalno (u oba smisla te riječi: i djelomično, i pristrano).

U tom sklopu ne bi bilo umjesno ne spomenuti barem neke od protagonista. Navesti ih valja makar usputno, ne pretendirajući ni izdaleka da je popis kompletan, pa ni rangiran.

Korifeji javne riječi kroz političke forume bili su dr. Ante Trumbić, dr. Josip Smodlaka, dr. Ivo Tartaglia, senator Budislav „Grga“ Angjelinović, liječnici Jakša Račić i Josip Berković, Prvislav Grisogono, svakako i „masovici“ Vicko Jelaska i File Vrcan, onda Paško Kaliterna, ing. Petar Senjanović, dr. Eduard Grgić, dr. Ljubo Leontić, dr. Silvestar Giunio. Među svećenstvom javnom riječju su prednjačili don Vinko Brajević, mons. Herkulan Luger, mons. dr. Urban Crisomali, o. Kerubin Šegvić te protojerej Sergije Urukalo. Višestruku ulogu na polju javne riječi imali su i neki književnici, poput Nike Bartulovića, Silvija Alfirevića, Marina Bege, povremeno Milana Begovića, Tina Ujevića, Đure Vilovića, pa Ive Andrića itd.

\footnotetext{
17 Budući da SAD nisu imale špijunsku mrežu u Njemačkoj, u početku Drugoga svjetskog rata su Lazarsfeld i Lasswell iznašli metode analize javnih glasila u svrhu pribavljanja podataka. Tu je analizu Lasswell već 1942. koristio za indiciranje ideoloških trendova, Berelson i njegova škola su 1953. pokazali široku upotrebljivost te metode za otkrivanje trendova koje nije moguće otkriti drugim metodama analize, a Naisbitt je to 1962. primijenio u marketinške svrhe.
} 


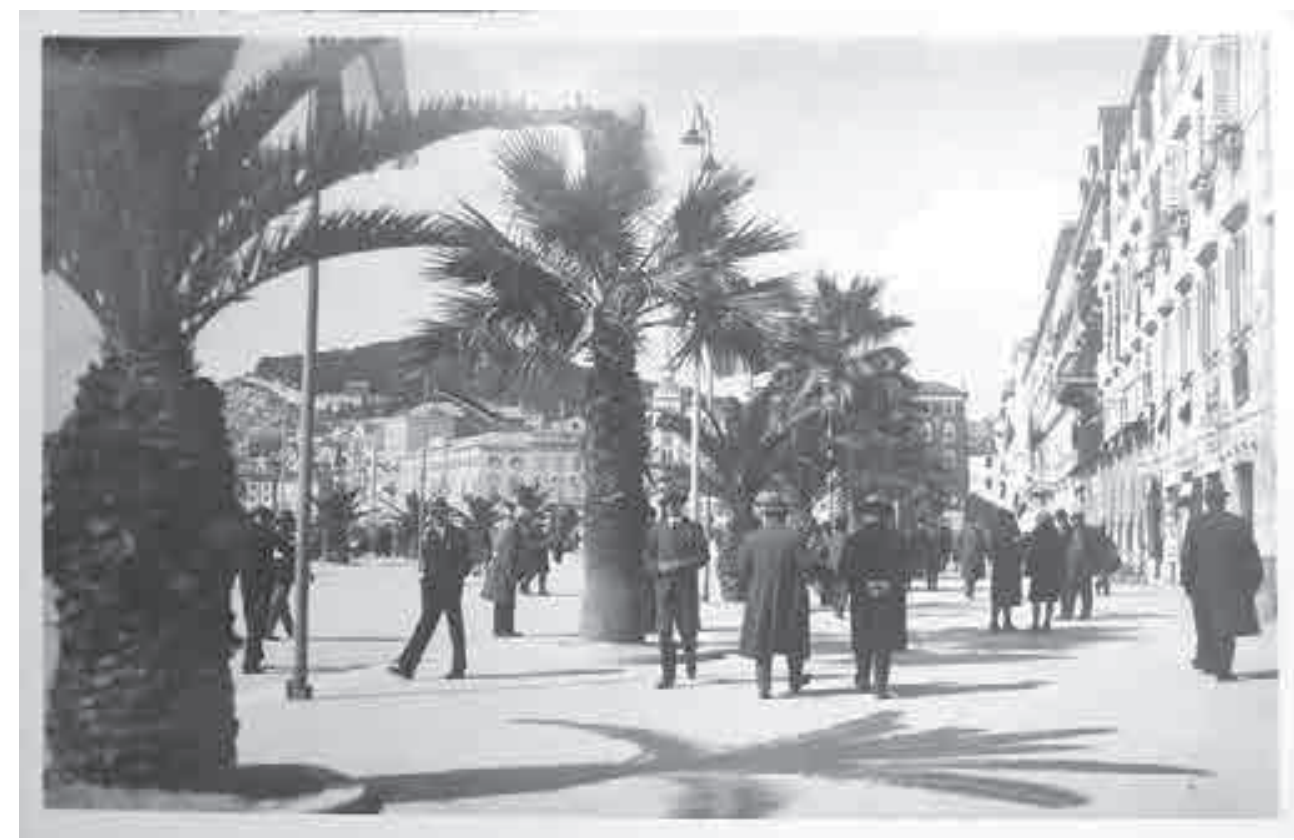

Sl. 1. Javna riječ odjekivala je i na Rivi

Neki među njima bili su predmetom istraživanja (Trumbić, Smodlaka, Tartaglia, sada i Šegvić, te književnici), ali većina drugih nisu. Bilo bi vjerojatno razloga za ispitivanje njihove uloge u tadašnjemu komunikacijskom prostoru.

\section{MEDIJI ORALNOG DISKURSA}

Ovdje se stoga nužno moramo ograničiti na plošan kroki, nadajući se da će on biti dopunjen zahvaljujući budućim istraživanjima. Glavne njegove crte, jer nam se čine najvažnijima za Split, jesu mediteranski forum publicum u Splitu, mediji masovnog komuniciranja te teatar kao medij javnog komuniciranja.

Splitski mediteranski forum, splitska agorá, uglavnom socijalno stratificiran areopag, nije bio samo na otvorenome. Pod krovom su bili Općinsko vijeće kao službeni, a kafana ${ }^{18}$ kao poluslužbeni rostrum, gotovo pa emanacija kora iz antičkog teatra, poglavito za legendarnim „stolom mudraca“, i jedan i drugi rezervirani za građansku klasu. Nostalgičnom pogledu na kafanu kao cjedilo za sukus gradske pameti suprotstavlja se posprdno kritičan stav. Hermann Bahr pozitivno je začuđen gremijem za „stolom mudraca“, a i Duško Kečkemet žali što nije sačuvan mogući splitski Florian. ${ }^{19}$ Anatolij Kudrjavcev pak tvrdi: „Pro-

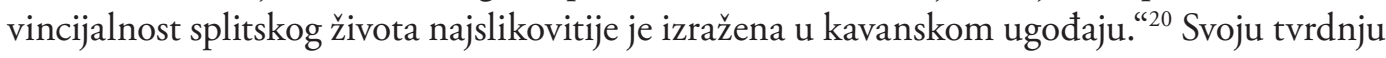

\footnotetext{
Kavana u splitskom vernakularu.

19 Duško KečKemet, Jučerašnji, današnji i sutrašnji Split (http://www.gkmm.hr/dusko_keckemet_jucerasnji_ danasnji_i_sutrasnji_split.htm).

20 Anatolij Kudruavcev, Vječni Split, Split 1985., 212.
} 


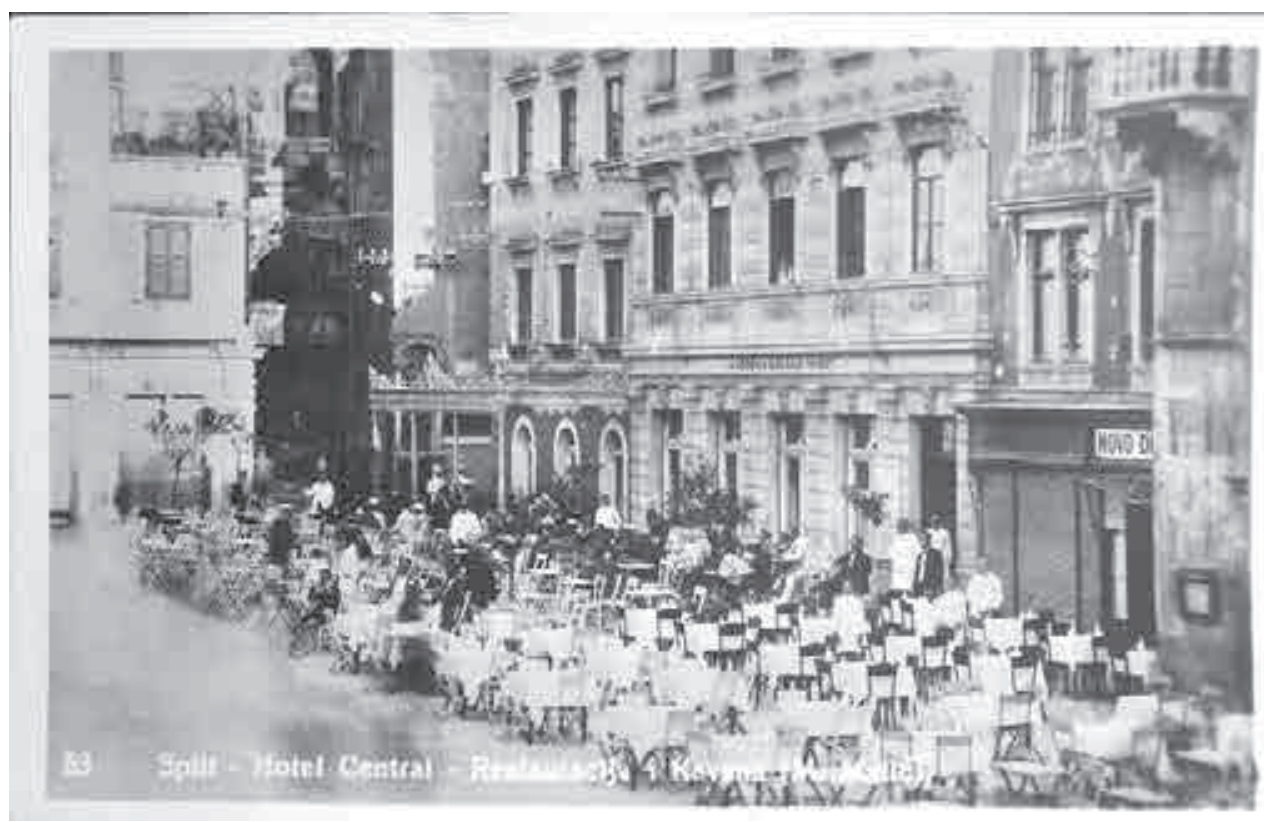

Sl. 2. „Provincijalnost splitskog života najslikovitije je izražena u kavanskom ugođaju.“ Kavana Hotela Central.

potkrepljuje prikladnim citatima Giulija Solitra, Sime Matavulja, Eugena Kumičića, Iva Vojnovića, pakosnoga gradonačelnika Vicka Mihaljevića, Bože Lovrića, napokon i Tina Ujevića, koga predstavlja kao kavanskog znalca - pa i taj ih u Splitu nalazi provincijskima. Vinko Lozovina, vjerojatno posve nehoteć, parafrazira Il'fa i Petrova, u čijemu Zlatnom teletu gospoda u prsluku sjede u kavani, listaju novine, te jedan kaže: „Jeste li čuli? Gandhi otišao u Dundee.“ Drugi zaključi: „Gandhi je glava“, a prvi ocijeni: „I Dundee je glava.“21 U Lozovininu rukopisu Zapisi s Vražjeg otoka spominje se „Stol Mudraca što stoluje na Narodnom trgu i proriče kao mnogoglava Pitija i Sibila sudbinu pojedincima i narodima svijeta". ${ }^{22} \mathrm{Ta}$ je mnogoglavost na svoje ocjene polagala i autorska prava. Marko Uvodić je u Novom dobu u svojoj rubrici skicirao u čakavštini specifične splitske macchiette koje je likovno karikirao njegov brat Angjeo Uvodić. Poslije raskida suradnje Uvodić je glavnog urednika don Vinka Brajevića tužio za povredu autorskih prava pa su u sudskoj raspravi Emanuel Vidović i Juraj Ćurić svjedočili da su karakteri tih macchietta kolektivna ideja nastala za „stolom mudraca“.23

Javni mitinzi bili su namijenjeni svim klasama - ali oni pripadaju u jednosmjernu komunikaciju. Reagiranje nazočnih teško da možemo smatrati elementom dijaloga, ne više nego smijeh ili pljesak u kazalištu, iako se interakcija ne smije ni tu negirati.

21 „САышали? - говориц один жимет Аругому, — Ганди приехам в Аанди. - Ганди - это голова! ... И Аанди -

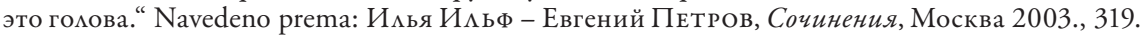

22 A. Kudrjavcev, Vječni Split, 215.

23 Ivanka Kuić, „Novo doba - najvažniji splitski i dalmatinski list između dva rata“, Kulturna baština, 41/2013., br. 39, 130. 
Razmjena mišljenja na Peškariji ${ }^{24}$ i Pazaru, ${ }^{25}$ koju samo uvjetno možemo uvrstiti u forum, pripadala je pučkome sloju. Bikarija, ${ }^{26} \mathrm{i}$ zbog svoga komornog prostora, nije bila za to pogodna. ${ }^{27}$

Interklasan karakter imala je brijačnica. U njoj su, naime, novine mogle biti čitane i komentirane besplatno, za razliku od kafane (to je vješto iskoristio Smoje ${ }^{28}$ ). Interklasan karakter imala je i crkva. U njoj je pak javna komunikacija, za razliku od brijačnice, bila isključivo jednosmjerna, izrazitije nego i na mitingu: od pulpita prema pastvi, bez izravnoga povratnog efekta.

Imanentan tip javne komunikacije u Splitu je i humor na bazi ruganja, odnosno ruganje koje se predočava kao humor. „Za volju jedne šale Splićanin bi žrtvovao sve od sebe“, tvrdi Bogdan Radica. ${ }^{29}$ Neke od šala koje je smišljao i s prijateljima elaborirao Vincenzo „šjor Vice" Bettiza, imale su sve značajke happeninga ante litteram, kadikad is golemom publikom (poput ispraćaja Marinka „Karuza“ u New York), pa se kvalificiraju za kategoriju javne riječi. Uostalom, njihov je rodonačelnik bio načelnik Vicko Mihaljević.

Medijsku funkciju u Splitu imao je, pa i prije i poslije tog razdoblja, teatar. ${ }^{30}$ I samozatajni Vladan Desnica ušao je u prostor javne riječi grada Splita takoreći kroz pokrajnja vrata: pišući kazališnu kritiku. Ali kazalište nije niša izvan svijeta, između njega i svijeta postoji dijalektika koju uočava još Epiktet, razrađuje Shakespeare, razvija Calderón kao Theatrum Mundi - ako tim autorima sav svijet jest glumište, jednako tako se, razglabajući teatar, piše o svemu svijetu. O javnoj riječi na pozornici izriče se javna riječ u novinama koja društvo cilja, katkad i strijelja, što na hrvatskom prostoru pratimo barem od Šenoe. Uostalom, uobičajena je pojava da književnost, a s njom svojedobno i glumište kao medij njezina uprizorenja, bude medij poruke (pa i eminentno političke, ponajčešće u društvima $s$ deficitom političke reprezentacije). ${ }^{31}$

U konkretnom društvu i u konkretno doba Milan Begović je u Jadranskoj pošti 5. svibnja 1928. tvrdio da u Splitu teatar „ne smije da bude samo institucija za zabavu nego i (...) živa potreba za sljubljivanje nacionalnog duha i otpora protiv svim neprijateljskim silama, koje nikad ne miruju“. ${ }^{32}$ Tako je u momentu podvaljivanja Nettunskih konvencija, koje je Vlada ratificirala dan nakon sprovoda Stjepana Radića, glumac Branko Kovačić u Maloj Floramye „zbog zabrane naše poštovane policije šjor Bepu da nosi talijansku vojničku kapu (...) uzeo kacigu od pumpjera i (...) naložio svom adjutantu da pozdravlja rukom

24 Ribarnici.

25 Tržnici.

26 Mesnica.

27 Premda je autor ovog članka prije 50-60 godina znao pribivati znakovitim razmjenama mišljenja, ne bez političke note, i u Mitrovićevoj mesnici, pretvorenoj jednom prilikom potkraj pedesetih godina - Split ima dara za paradoks - u pozornicu Seviljskog brijača na Splitskim ljetnim priredbama.

28 Miljenko Smoje, Velo misto, Split 2004.

29 Bogdan Radica, Vječni Split, Split 2002., 283. Paralelna je s time toskanska uzrečica: „È meglio perdere un amico che una battuta.“ U prijevodu: „Bolje je izgubiti prijatelja nego dosjetku.“

30 U užem smislu: kazalište, zgrada na Bulatovoj poljani, u širem smislu: glumište.

31 Više o tome u: Inoslav BEŠKER, I Morlacchi nelle letteratura europee, Roma 2007., 253.

32 Antonija Bogner-ŠABAn, „Splitsko kazališno društvo“, Dani Hvarskog kazališta, sv. 29: Hrvatska književnost i kazalište dvadesetih godina 20. stoljeća, Zagreb - Split 2003., 192-230. 
u vis kao pravi potomak rimskih kvirita“, što je zapisao Ivo Lahman u Novom dobu 29. svibnja $1928 .^{33}$

Između početka tog razdoblja - kada je Teatar bio degradiran na skladište za aprovizaciju, uključujući i distribuciju mekinja - i kraja - kada se splitsko Hrvatsko narodno kazalište, na budžetu Banovine Hrvatske, nasukalo na Rimskim sporazumima koje je otišao potpisati i pravaš don Kerubin Šegvić - naslovi s kazališnog repertoara mogu opisati, možda i čitkije, istu parabolu koju je slijedila orijentacija Novoga doba. Po svemu sudeći, tu je parabolu - od antiiredentističke podrške jugoslavenstvu do snažnije afirmacije hrvatstva - slijedila i glavnina puka, a i poneki znatniji političar proistekao iz splitskog puka: Ante Trumbić, primjerice, prešao je putanju od Jugoslavenskog odbora do Zagrebačkih punktacija.

\section{MEDIJI MASOVNOG KOMUNICIRANJA}

Na samome početku razdoblja koje je bilo tema Desničinih susreta 2015. (1918. - 1945.), od medija masovnog komuniciranja Splićanima je dostupan samo tisak, spram kojega postoji dvojan odnos kao i danas, ali s različitim polovima. Danas, s jedne strane, opstaje radoznalost prema informacijama koje su u tisku iznesene, iz godine u godinu sve manja, $s$ druge strane njoj se suprotstavlja sve veće nepovjerenje kako u sadržaj tih informacija tako i u namjere zašto su odabrane baš te informacije i zašto su prezentirane baš na taj način.

U godinama neposredno nakon Prvoga svjetskog rata - kada je pad glavnoga grada $\mathrm{Za}$ dra pod talijansku vlast naprasno promovirao Split, dotad već industrijsko središte Kraljevine Dalmacije, i u administrativni centar te dok je kulturalna invazija Antantinih posada ključno pridonosila transformaciji stila života „gornje tisuće“ Splićana iz statike o kojoj svjedoči Hermann Bahr 1909. ${ }^{34}$ u dinamiku „ludih dvadesetih“35 - na jednom polu je činjenica da novine jedine nude ažurnu informaciju iz grada, doma i svijeta, a na drugome zazor zatvorene sredine spram notornosti, izražene sintagmom da su nekoga "dali u foje“ ili prijetnjom „dat ću te u novine“, koja je opstajala i dugo poslije Drugoga svjetskog rata. ${ }^{36}$

$\mathrm{Na}$ kraju tog razdoblja radio je već nudio informacijsku globalizaciju, koja se u Drugome svjetskom ratu koristila i u propagandne svrhe i za širenje prostora javne riječi. Radio je omogućio simbiozu krajnje ažurne informacije (koja više nije odgađana međufazom tiska i distribucije) i zabave kroz muzički program, otvarajući tako i put u infotainment, ali to je okvir javne riječi za neka kasnija i sadašnja doba, ne za ono koje je i za Vinka Kisića i za Splićane bilo obuhvaćeno nazivom Novo doba.

$\mathrm{Na}$ početku 20. stoljeća sami političari uređuju novine. ${ }^{37}$ Tako u Splitu pravaš Ante Trumbić uređuje svoj Velebit, a Josip Smodlaka, također pravaš, svoju Slobodu, uz pomoć

\footnotetext{
33 Isto, 192.

34 Hermann BAHr, Dalmatinische Reise, Berlin 1909.

35 A. Kudrjavcev, Vječni Split 242-243. To je istražio i Vjekoslav Perica.

36 Osobno iskustvo autora. Podatak da novine o nekome pišu nije nužno bio pokazatelj popularnosti, nego je služio i kao „licenca“ za ukazivanje prstom, sve do ruganja i, u krajnjim slučajevima, kreiranja „ridikula“, tj. žrtve masovnog ruganja.

37 Vojko Mirković, „Dalmatinsko novinstvo“, Dalmacija - hrvatska ruža svjetova (ur. Marin Kuzmić i Ante Mekinić), Split 2012., 164-166.
} 
braće Ive i Oskara Tartaglie. Potkraj Prvoga svjetskog rata, od početka 1918., počinje ekspanzija periodičnog tiska kao medija javne riječi. U desetak godina, do 6. siječnja 1929., u Splitu se pojavilo oko 70 naslova novina koje su izlazile kraće ili dulje. ${ }^{38}$ Znatnije među njima popisuje i prikazuje Božo Novak, ${ }^{39}$ a mnogo minucioznije Zdravka Jelaska Marijan, što ovdje nema smisla prepričavati. ${ }^{40}$ Zadržat ćemo se samo na jednome.

To je dnevnik Novo doba, koji je pokrenuo u lipnju 1918. i uređivao Dubrovčanin Vinko Kisić, ${ }^{41}$ dotad urednik u redakciji zadarskog Narodnog lista. Novo doba je „prvi dnevni političko-informativni list koji je uspio održati kontinuitet izlaženja više od dvadeset godina, tj. od konca Prvoga do početka Drugoga svjetskog rata i tako stoji ravnopravno uz bok mnogim zagrebačkim uspješnim novinama“. ${ }^{42}$ Iako je pokrenut marom korifeja javne riječi (od kojih smo neke spomenuli), stranački neovisnih, ali bliskih jugoslavenski orijentiranoj Demokratskoj stranci, ${ }^{43}$ on tvori „prekretnicu u povijesti splitskog novinstva jer označava prijelaz na moderan, građanski način informiranja, koji nije vidljivo politički obojen, nego širi ideologiju građanskog zajedništva“, tvrdi Kuić. ${ }^{44}$ Sam list pak, pro domo sua, piše sredinom lipnja 1928. na naslovnoj stranici da je Novo doba ostalo „čvrstim braniteljem jugoslavenske misli i jugoslavenskog barjaka“" 45

List je, zapravo, pratio parabolu javnog mnijenja do atentata na Radića i poslije njega. Tako je kroza sve vrijeme imao nakladu od oko 7000 primjeraka, što pokazuje da je tolikom broju čitatelja odgovarala pozicija koja je u dvadesetim godinama bila bliska jugoslavenstvu, usmjerena protiv talijanskog iredentizma, a potkraj tridesetih, u doba glavnog urednika don Vinka Brajevića, ${ }^{46}$ orijentacija „u prilog hrvatskoga narodnog pokreta odnosno politike HSS“, po izvješću Ispostave banske vlasti $1940 .{ }^{47}$ Insajderi novinari Josip Kortšek i Jerolim Čogelja navode da je Novo doba pod obojicom glavnih urednika bilo „daleko od svake partijske zajedljivosti“ i „,daleko od svih ličnih uvreda, intriga i podvala“.48

Među novinarima su na rostrumu Novog doba bili i Ulderico Donadini, Joe Matošić, Vladan Desnica, Ćiro Čičin-Šain i drugi znatniji pisci iz Splita, ili oni koji su u Splitu privremeno boravili.

Novo doba te, u razmjerno manjoj mjeri, Jadranska pošta, Jadranska straža, Jadranski dnevnik itd. bili su, u naznačenu razdoblju, pak glavni medij javne riječi: pronosili su što je zabilježeno na inim forumima te ono što su smatrali vrijednim objavljivanja kao vlastit prinos. Utoliko su ti listovi, ipak više od ičega, dokument javne riječi u međuratnom Splitu.

38 I. Kuić, „Novo doba“, 15.

39 Božidar NovaK, Hrvatsko novinarstvo u 20. stoljeću, Zagreb 2005., 106-107.

40 Zdravka Jelaska Marijan, Grad i ljudi: Split 1918.-1941., Zagreb 2009., 460-468.

41 J. Horvat, Povijest novinstva Hrvatske, 382.

42 I. Kuić, „Novo doba“, 114.

43 Tako Kisić definira Novo doba izrijekom u pismu Toniju Schlegelu 1926. u zagrebačku Jugoštampu, kada predlaže da osnuju zajedničku telefonsku službu u Beogradu, radi uštede, ali to je pismo motivirano i financijskim nevoljama „Novog doba“. Usp. I. Kuić, „Novo doba“, 118.

44 Isto.

45 „Desetogodišnjica 'Novog doba'.", Novo doba (Split), br. 140, 17. 6. 1928., 1.

46 Od 1922. pomoćnik glavnog urednika, a od Kisićeve smrti 1927. glavni urednik.

47 Z. Jelaska Marijan, Grad i ljudi, 463.

48 Usp. B. Novak, Hrvatsko novinarstvo u 20. stoljeću, 253; Z. Jelaska Marijan, Grad i ljudi, 463; Frano Baras, Staro zrcalo splitsko, Split 1994., 67. 


\section{UTJECAJ NA KASNIJE NARAŠTAJE}

Prateći tri novinarske sudbine iz tog doba moguće je, također, uvidjeti koliko je standard javnog novinskog diskursa u Splitu u međuratnom razdoblju utjecao, dugoročno, a u nekim elementima i presudno, na razvitak standarda novinstva i javnog komuniciranja u ratnom razdoblju, dakle u posljednjem odsječku razmatranog perioda, ali i u poraću, posredno sve do kraja 20. i početaka 21. stoljeća.

Pozornost su nam privukla trojica novinara, formirana u splitskome obavijesnom miljeu, čiji je utjecaj ostao uglavnom u okvirima uredničkih soba i zbog toga ostao nezamijećen široj publici. To su, abecednim redom: Ivo Baljkas (1892. - 1977.), Jerolim Čogelja (1899. - 1990.) i Josip Kortšek (1899. - 1981.).

Ivo Baljkas, Šibenčanin, u hrvatskoj je javnosti poznatiji po svome političkom radu, kao akter „lijeve frakcije“ u KPJ u Dalmaciji s Ivanom Marićem i Vickom Jelaskom, nego po novinarskome, u kojemu je stavio dulji i dublji trag. Kao već formiran socijaldemokrat, od 1912. radi u šibenskome Crvenom barjaku. Poslije internacije pa mobilizacije u AustroUgarskoj pokrenuo je 1919. Crveni vijak s „K. Brajerom i V. Matačićem““49 U svibnju te godine počeo je raditi kao odgovorni urednik splitskog Oslobođenja, koje je uređivao do kraja 1920., kada je protjeran iz Splita u Šibenik. ${ }^{50}$ Šibenske novine Fabrika i njiva uređivao je od 1923. U proljeće 1925. godine imenovan je urednikom zagrebačke Radničke borbe, koja tada izlazi kao organ legalne Nezavisne radničke partije Jugoslavije. U splitskoj Jadranskoj pošti radio je od 1927. do 1928. Te je godine 1. ožujka pokrenuo Radnički odjek, zabranjen već 15 . rujna. ${ }^{51}$ Uslijedio je politički interregnum (profesionalni partijski rad, emigracija u Argentini 1929. - 1936., pa kraće u Parizu, opet politički rad u Dalmaciji do isključenja iz KPJ 1939. poslije sukoba s Josipom Brozom, internacija u Italiji 1941. - 1943.). Odmah nakon toga, tijekom i poslije Drugoga svjetskog rata bio je urednik u splitskoj Slobodnoj Dalmaciji, ${ }^{52}$ potom zamjenik glavnog urednika u zagrebačkom Vjesniku, ${ }^{53}$ urednik u zagrebačkome Narodnom listu, a od 1953. do umirovljenja 1956. lektor i redaktor u Vjesniku $u$ srijedu, ${ }^{54}$ gdje je nastavio više godina honorarno raditi isti posao. ${ }^{55}$

U Vjesniku, Narodnom listu i osobito u Vjesniku u srijedu, Baljkas je znatno utjecao na kulturu novinskog pisma u Hrvatskoj. Njegova minuciozna sadržajna i stilska redaktura, koja je znala preći i u rewriting, pridonijela je u osjetnoj, a katkad i u znatnoj mjeri formiranju diskurzivnog stila kojim se Vjesnik u srijedu isticao među novinama u Jugoslaviji pedesetih i šezdesetih godina, a ništa manje i informacijskog standarda, baziranoga na zapravo

\footnotetext{
49 Mladen ŠvaB - Tonči Šitın, „Baljkas, Ivo“, Hrvatski biografski leksikon (http://hbl.lzmk.hr/clanak.aspx?id=1203).

50 Petar PožAr, Leksikon povijesti novinarstva i publicistike, Split 2001., 47.

51 M. ŠvaB - T. Šitin, „Baljkas, Ivo“.

52 Vojko Mirković, „Učili ribare solit srdele“, Slobodna Dalmacija (Split), 12. 6. 2003. (http://arhiv.slobodnadalmacija hr/20030612/feljton01.asp); Vojko Mirković, „Urednici - potrošna roba“, Slobodna Dalmacija (Split), 14. 6. 2003. (http://arhiv.slobodnadalmacija.hr/20030614/feljton01.asp).

53 P. PožAR, Leksikon povijesti novinarstva i publicistike, 47.

54 M. ŠVAB - T. ŠItin, „Baljkas, Ivo“.

55 P. PožAR, Leksikon povijesti novinarstva i publicistike, 47.
} 
časopisnoj akribiji. ${ }^{56}$ Dugo se, u tom smislu, spominjala „Baljkasova škola“.${ }^{77}$ Budući da su novine bile dugo jedina škola novinarstva, mirne se duše može reći da su javnosti nepoznati redaktori, a Baljkas na prvome mjestu, bili nevidljiva škola novinarskih naraštaja koji su u Hrvatskoj stasali od sredine pedesetih do kraja šezdesetih godina.

Jerolim Čogelja, također Šibenčanin, u Berlinu je 1920. pohađao novinarsko učilište koje su osnovali socijaldemokrati. ${ }^{58}$ Po povratku u zemlju surađivao je u splitskome Novom dobu i Jadranskoj straži te kao splitski dopisnik u zagrebačkim listovima Obzoru, Jutarnjem listu i Večeri. Kao vlasnik i urednik izdavao je 1924. u Karlovcu Karlovački hrvatski glas, a 1938. pokrenuo je u Splitu utjecajni tjednik za pomorsku privredu Jadranski Lloyd. ${ }^{99}$ U Slobodnu Dalmaciju ušao je na Visu $1944 .{ }^{60}$ U njoj je uređivao privrednu rubriku do 1949., zatim je bio njezin dopisnik iz Zadra, gdje je organizirao ponovno izlaženje Narodnog lista. Bio je direktor zadarskoga Narodnog kazališta 1951. - 1952. ${ }^{61}$ U Splitu je od 1957. do umirovljenja 1959. bio zamjenik glavnog urednika Slobodne Dalmacije, a zatim do 1962. dopisnik zagrebačkog Vjesnika iz Zadra.

U Slobodnoj Dalmaciji „Čogelja je novinare početnike učio kako da se oslobode suhog činovničkog jezika i da u svoje pisanje unesu malo srca i topline “. ${ }^{62}$ Među novinare koji su se formirali pod dnevnom paskom i usmjeravanjem Jere Čogelje pripada Miljenko Smoje. Mirno se može reći da se kroz njegov rad, te kroz rad novinara koji su prošli istu vrstu staža, npr. Davorina Rudolfa, Vojka Mirkovića, pa i Joška Kulušića - a taj je rad u pojedinim rodovima označio vrhunce hrvatskog novinarstva u drugoj polovici 20. stoljeća - izrazito nastavila i razvila škola javne riječi započeta u Novome dobu.

Josip Kortšek, Splićanin, započeo je kao nakladnik i odgovorni urednik satiričnoga lista Električne stranice u Splitu 1920. godine. Ubrzo je postao novinarom Novog doba, a potom članom njegova uredništva. Godine 1925. postao je splitskim dopisnikom zagrebačkih Novosti te je ustrojio njihovo dopisništvo s mrežom suradnika. Zatvaran za ustaške vlasti, pristupio je partizanima. Potkraj 1944. postao je urednikom vijesti u Slobodnoj Dalmaciji, a 1945. - 1951. bio zamjenik glavnog urednika. ${ }^{63}$ I Kortšek je utjecao na to da se kultura novinskog diskursa, razvijana u Novom dobu i u njegovu dopisništvu Novosti, ukorijenila kao normativna i u razdoblju nakon 1945 . godine.

Slobodna Dalmacija je svoj rad na Visu, a nakon oslobođenja Splita 26. listopada 1944. i u svom gradu, temeljila baš na predratnim iskusnim novinarima mahom iz Novog doba. ${ }^{64}$

$\overline{56}$ Baljkas je znatno pridonio izgledu i standardu vanjskopolitičkih osvrta koje je Ive Mihovilović pisao pod pseudonimom Spectator.

57 Njezin važan izdanak je novinar i pisac Marko Grčić Rako. I potpisani autor je, dolazeći po redaktorske i lektorske savjete Baljkasu u VUS, uspio upiti nešto njegova znanja i iskustva.

Srećko Ljubljanović, „Čogelja, Jerolim“, Hrvatski biografski leksikon (http://hbl.lzmk.hr/clanak.aspx?id=4076).

Isto.

60 V. Mirković, „Učili ribare solit srdele“.

61 S. Ljubljanović, „Čogelja, Jerolim“.

62 V. Mirković, „Učili ribare solit srdele“.

63 Šimun Jurišıć, „Kortšek, Josip“, Hrvatski biografski leksikon (http://hbl.lzmk.hr/clanak.aspx?id=10101).

64 „U jubilarnom broju Slobodne Dalmacije od 17. lipnja 1983. književnik Marin Franičević tvrdio je da je proveo nekoliko ratnih mjeseci kao urednik Slobodne Dalmacije. Opisuje pojedinosti. Došao je iz Barija u tek oslobođeni Split i svratio u Oblasni komitet KPH. Naišla je Anka Berus, vjerojatno u to doba najistaknutija hrvatska komunistkinja, i naredila mu da preuzme Slobodnu Dalmaciju kao glavni urednik. Čak mu je naložila da odmah napiše uvodnik 


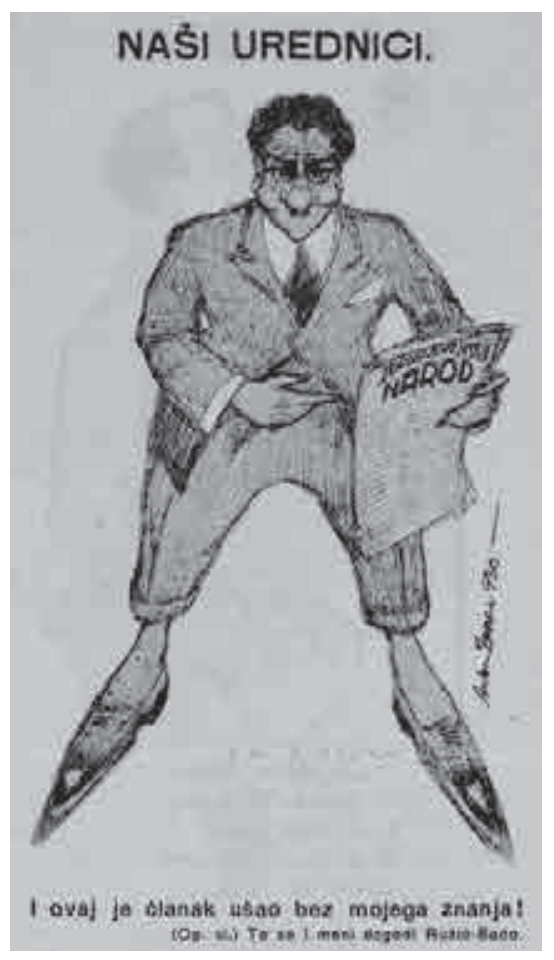

Sl. 3. Duje Balavac o uredničkoj slobodi u svibnju 1923. godine. Karikatura Antuna Zuppe.

Kortšek, Čogelja i Baljkas bili su, zapravo, kičma redakcije, dok su glavni urednici bili „potrošna roba“65 koja je stizala i odlazila po političkim kriterijima. Jedan od tadašnjih početnika ovako je opisao svoj ulazak u redakciju: „Kada je prvi put došao u redakciju sekretarica ga je uvela kod urednika Kortšeka, a on ga je uputio Čogelji. Barba Jere mu je rekao da čita komplete starih novina i vidi kako se piše i što listu treba." ${ }^{\text {"66 }}$ Prema tome, prvi korak u uvođenju početnika u novinarski posao bilo je proučavanje samog medija, upoznavanje s tematikom te usvajanje diskursa i stila već objavljenih priloga. „A onda ga je jednog dana uputio u Poljoprivrednu školu da nešto pita direktora. Tako je počeo pisati." ${ }^{67}$ Taj se početnik zvao Miljenko Smoje. ${ }^{68}$

Kortšek i Baljkas su eliminirani iz redakcije u jednoj od „čistki informbiroovaca“. Pritisak Partije i policije ${ }^{69}$ bio je takav da se Kortšek, po Smojinu svjedočenju, pokušao ubiti zabijajući sebi čekićem čavao u glavu. ${ }^{70}$ Optužbe su pale, Kortšek je umirovljen, ali je od 1966. do 1972. bio izvršni urednik boračkog periodika Poruka borca, ${ }^{71}$ što se može smatrati punom rehabilitacijom i pečatom „pravovjerja“, dok je Baljkas, kako smo vidjeli, prešao u Zagreb na istaknut položaj zamjenika glavnog urednika Vjesnika.

Dok su novinski diskurs održavali i razvijali novinari razvijeni i međuratnom Splitu, Slobodna Dalmacija imala je solidan prijem. Čogelja je kasnije svjedočio da je u prvim poslijeratnim godinama naklada lista bila od 14 do 15 tisuća primjeraka. Međutim, sedamosam godina poslije, „kada su nagle personalne izmjene u redakciji dovodile do raznih gledišta o ulozi lista i kada se počelo misliti da je za 'Slobodnu' najbolje da što više sliči na 'Borbu' ili druge centralne listove, tiraž je počeo vrtoglavo padati“, prenosi Mirković. ${ }^{72}$

protiv nabijanja cijena i skrivanja robe u trgovinama... M. Franičević navodi koga je tih dana zatekao u redakciji: Josipa Kirigina, Živka Jeličića, Nevena Šegvića, Jeru Čogelju, Josipa Kortšeka, Ivu Lapendu, Ivu Baljkasa, koji je bio lektor, Anticu Guić, koja je počela kao korektor." Usp. V. Mirković, „Učili ribare solit srdele“.

65

66

67 Isto.

68 „Sjećam se, na primjer, da su mi neki govorili za mojega učenika Miljenka Smoju da nije bogzna kakav talent, dok sam ja bio duboko uvjeren da će se razviti u vrsnog novinara. Vjerujem da će mi Smoje oprostiti što sam ga kao urednik znao ponekad pozvati i pokazati na stolac pored mojega stola i reći: 'Hajde, sjedi da ovo zajednički prostudiramo'“. Isto.

69 Smoje tako definira. Usp. V. Mirković, „Urednici - potrošna roba“. Vjerojatno je posrijedi Uprava državne bezbjednosti.

70 V. Mirković, „Urednici - potrošna roba“.

71 Š. Jurišić, „Kortšek, Josip“.

72 V. Mirković, „Učili ribare solit srdele“. 


\section{ZAKLJUČAK}

Javna riječ u međuratnom Splitu koristila je više komunikacijskih kanala, paralelnih ali nerijetko isprepletenih, kojima se mogla iskazivati i razvijati. Djelovala je i u javnom životu, od političkih i kulturalnih institucija do trga i ulice (jer su i ti prostori, u društvenoj i komunikacijskoj strukturi Splita kao tipičnoga i karakterističnoga mediteranskoga grada, bila poprišta javnog komuniciranja), ali i medijski, kroz tisak (u početku tog razdoblja jedini medij, a i potkraj tog razdoblja itekako pretežan).

Unatoč bogatstvu oblika i kanala, područje akcije i interakcije javne riječi u Splitu prilično je neistraženo. Aktera zapravo više nema, a veoma je malo i svjedoka. Stoga novine, kao ne samo sekundaran, nego i primaran izvor, ostaju gotovo jedino relevantno vrelo za istraživanje javne riječi u Splitu 1918. - 1945. Uostalom, i u samome tom razdoblju, kada je javna riječ u Splitu koristila više komunikacijskih kanala, novinski medij je među njima bio privilegiran distribucijski, kao jedini instrument masovnog komuniciranja, i o društvu, i u društvu. Imao je još dvije prednosti za današnjeg istraživača: zrcalio je i ostale kanale, a po svojoj naravi ostao je dostupan.

Ova rasprava je nastojala naznačiti neke od mogućih smjerova daljnjeg istraživanja javnog i generalnog diskursa u onodobnom Splitu. Osim ostaloga, otvorila je i pitanje odnosa međuratnoga i poratnog diskursa, usredotočivši se, doduše, tek na jedan uzak, ali znakovit segment medijskog djelovanja: uređivanje dnevnih i tjednih novina. I tu se pokazalo da su informativni, a i kulturalni standardi, koji su do 1941. postavljeni u splitskome međuratnom novinstvu, pozitivno utjecali na razinu novinskog diskursa u Hrvatskoj nakon Drugoga svjetskog rata te da se žurnalistička kultura npr. Novog doba ili Jadranskog Lloyda reproducirala i poslije 1945., ne samo u Splitu.

\section{es}

\section{Public Discourse in Interwar Split}

Public discourse in Split between the two World Wars resonated in two kinds of spaces, in the physical space and the media space, that is, in the spoken discourse and the written discourse. This is a rather unexplored area. In that regard, the article points out some of the possible directions in further research of public and general discourse in Split in the interwar period, and of its influence on the development of media discourse in Croatia after World War II. The physical space of the public discourse in Split was a local version of the Mediterranean forum: the institutional Municipal Council, the coffee house set up as the classical chorus (with the crypto-institution of the "table of the wise"), the market and the fish market as places of exchange of ideas and not only goods. The real space of public discourse also includes theatre, one in the theatre house (which is also the place if not of exchange, then of the induction of ideas), and the other in the streets, the site of the carnival which took place once a year as well as the site of mockery and sometimes cruel jokes throughout the year. In the period under examination the only medium is the press, since radio only appears by the end of period (and only as reception). The press is dominated by the newspa- 
pers as a purveyor of the news but also as a mirror of public discourse delivered in other contexts and partially recorded. The newspapers reported the material reported in other forums, and the material they considered worthy of publication as their own contribution. In that regard, the Split newspapers from the period serve not only as a secondary historical source, but frequently also as a primary one. They thus represent significant documents of public discourse in interwar Split. The standards of newspaper discourse generated in interwar Split influenced, by way of the protagonists themselves (Ivo Baljkas, Jerolim Cogelja, Josip Kortšek, etc.), the standards of newspaper discourse in Croatia after World War II. The journalistic culture of, for instance Novo doba or Jadranski Lloyd, reproduced itself after 1945, and not only in Split.

Key words: Split, the inter-war period, public discourse, media discourse, newspapers, Ivo Baljkas, Jerolim Čogelja, Josip Kortšek

\section{$\cos$}

\section{Literatura}

Herman BAHr, Dalmatinische Reise, Berlin1909.

Frano Baras, Staro zrcalo splitsko, Split 1994.

Inoslav BEŠKER, I Morlacchi nelle letteratura europee, Roma 2007.

Antonija Bogner-ŠABAn, „Splitsko kazališno društvo“, Dani Hvarskog kazališta, sv. 29: Hrvatska književnost $i$ kazalište dvadesetih godina 20. stoljeća, Zagreb - Split 2003., 192-230.

Andrew Boyd, Broadcast Journalism. Techniques of Radio and TV News, Oxford 1994.

Umberto Eco, „Obiettività dell'informazione: il dibattito teorico e le trasformazioni della società italiana“, u: Umberto Eco - Marino Livolsi - Giovanni Panozzo, Informazione, consenso e dissenso, Milano 1979., 15-51.

Gilles Feyel, „Aux origines de l'éthique des journalistes: Théophraste Renaudot et ses premiers discours éditoriaux (1631-1633)“, Le Temps des médias, 1/2003., br. 1, 175-189 (http://www. histoiredesmedias.com/Aux-origines-de-l-ethique-des.html\#2).

Eugène Hatin, Histoire politique et littéraire de la presse en France, sv. 1, Paris 1859.

Josip Horvat, Povijest novinstva Hrvatske 1771-1939., Zagreb 1962.

Zdravka Jelaska Marijan, Grad i ljudi: Split 1918.-1941., Zagreb 2009.

Christian Jounaud, Les pouvoirs de la littérature. Histoire d'un paradoxe, Paris 2000.

Šimun JuRIŠIĆ, „Kortšek, Josip“, Hrvatski biografski leksikon (http://hbl.lzmk.hr/clanak. aspx?id=10101).

Milan Kangrga, „Etika i novinarstvo“, Medijska istraživanja, 4/1988., br. 1, 17-27.

Duško KečKemet, Jučerašnji, današnji i sutrašnji Split (http://www.gkmm.hr/dusko_keckemet_jucerasnji_danasnji_i_sutrasnji_split.htm).

Anatolij KudrJavcev, Vječni Split, Split 1985.

Ivanka KuIĆ, „Novo doba - najvažniji splitski i dalmatinski list između dva rata“, Kulturna baština, 41/2013, br. 39, 113-138.

Jean Lacouture, Les impatients de l'histoire, Paris 2009.

Srećko Ljubljanović, „Čogelja, Jerolim“, Hrvatski biografski leksikon (http://hbl.lzmk.hr/clanak. aspx?id=4076). 
Vojko Mirković, „Dalmatinsko novinstvo“, Dalmacija - brvatska ruža svjetova (ur. Marin Kuzmić i Ante Mekinić), Split 2012., 164-166.

Vojko Mirković, „Učili ribare solit srdele“, Slobodna Dalmacija (Split), 12. 6. 2003. (http://arhiv. slobodnadalmacija.hr/20030612/feljton01.asp).

Vojko Mirković, „Urednici - potrošna roba“, Slobodna Dalmacija (Split), 14. 6. 2003. (http://arhiv.slobodnadalmacija.hr/20030614/feljton01.asp).

Božidar NovaK, Hrvatsko novinarstvo u 20. stoljeću, Zagreb 2005.

Petar PožAR, Leksikon povijesti novinarstva i publicistike, Split 2001.

Bogdan Radica, Vječni Split, Split 2002.

Miljenko Smoje, Velo misto, Split 2004.

Mladen ŠvaB - Tonči Šitın, „Baljkas, Ivo“, Hrvatski biografski leksikon (http://hbl.lzmk.hr/clanak. aspx?id=1203). 